\title{
Kefir - a fermented milk product beneficial for gastrointestinal health
}

\author{
Sonanki Mitra ${ }^{1}$ and Bikash C Ghosh ${ }^{2}$
}

Received: 9 September 2021 / Accepted: 6 December 2021 / Published online: 22 December 2021

(C) Indian Dairy Association (India) 2021

\begin{abstract}
Kefir is becoming increasingly popular as a result of new research into its health benefits. It is a fermented product which originated in the Caucasus Mountains of Russia. Kefir is produced by the action of bacteria and yeasts existing in symbiotic association in kefir grains. The composition of kefir varies according to the type of milk and the microbiological composition of culture types (kefir grain or commercial starter culture). Kefir's distinctive flavour is attributed by lactic acid, ethanol, carbon dioxide and other flavouring agents, such as acetaldehyde and acetoin. The microorganisms in kefir produce vitamins, degrade protein and hydrolyse lactose making it a highly nutritious and digestible product. Kefir has a long history of health benefits in Eastern European countries. In this review, manufacturing technologies, physicochemical properties, microbiological composition, therapeutic activities (viz. antimicrobial, anticarcinogenic, immunomodulatory, probiotic properties etc.) as well as other health benefits, like reducing cholesterol and improving lactose tolerance have been summarised.
\end{abstract}

Keywords: Gastrointestinal benefits, Fermented milk product, Kefir, Therapeutic properties

${ }^{1}$ Quality Assurance Executive, GCMMF Ltd., Vadodara -9, Gujrat, India

${ }^{2}$ Dairy Technology Section, SRS, ICAR-National Dairy Research Institute, Bengaluru, India

Bikash C Ghosh $(\square)$

Dairy Technology Section, SRS

ICAR- National Dairy Research Institute

Adugodi, Bengaluru - 560030, India

E-mail: ghosgoga@hotmail.com

\section{Introduction}

From prehistoric time, the manufacture of acidified milk products have been known in all countries. Acidification mostly depends on lactic acid bacteria (LAB) naturally present in milk that yield lactic acid required for coagulation. When these LAB are accompanied by yeasts or moulds they provide distinct features to the cultured product. Researches all over the world revealed the significance of fermentation as a way of conservation, preservation, improvement of nutritive value as well as enhancement of sensory characteristics. Evidences show that Kombucha (fermented black or green tea drinks) manufacture dates back to approximately 220 B.C. (Dufresne \& Farnworth, 2000), while recent proteomic analysis have shown that Kefirlike milk to have been fermented some 3500 years ago in Asia (Yang et al. 2014). The universal functional beverage market is a developing part of the food trade as present-day health-conscious end users show growing appetite for foods that can enhance well-being along with lowering the risk of diseases.

Kefir is an energising cultured milk beverage with an exotic sour and slightly alcoholic flavour. It is prepared by inoculating milk with kefir grains. These grains are small unevenly shaped, yellowish-white, granules similar to cauliflower florets. A typical kefir is fizzy and have pourable consistency. It is a self-carbonated beverage with a distinctive flavour due to a mixture of lactic acid, ethanol, carbon dioxide and other flavour compounds namely acetaldehyde, acetoin etc. There is a symbiotic relationship between bacteria and yeast (Vedamuthu, 1977). According to Koroleva (1988) yeasts in Kefir enhance the activity of the lactic acid bacteria by supplying them growth stimulants as well as processing some of the lactic acid.

\section{Kefir -A brief history}

Kefir has been originated from Turkish words "keyif" meaning pleasure and "kopur" meaning milk or froth. The herdsman of Caucasus discovered Kefir while transferring milk in leather pouches as the milk would ferment to develop into an effervescent and appetizing drink. Thus, they started making Kefir by adding Kefir grains to milk in leather pouches and hanging them near doorways thereby stirring the fillings when someone knocked 
the bag while walking through the doorways. It is said that in the early part of the 20th century, a Russian lady named Irina Sakharova persuaded a prince in the Caucasus to provide her few Kefir grains. She began producing Kefir in Moscow and ever since then it has been a Russian primary food.

Kefir is a traditional fermented dairy product of Middle East. It originated from Caucasus Mountains in former Soviet Union, Central Asia. It is thick self-carbonated beverage with a smooth, marginally foamy body and whitish hue having very small portion of alcohol. It is produced by fermentation of milk with kefir grains or mother culture prepared from the grains. Kefir can be prepared from any type of milk such as cow, goat, sheep, coconut, rice and soy but commonly cow milk is used (Irigoyen et al. 2005). Apart from these, milk can be pasteurized, unpasteurized, whole fat, low fat, skim and no fat.

The following description of Kefir has been given by Codex Alimentarius: Starter culture prepared from Kefir grains, Lactobacillus kefir, and species of the genera Leuconostoc, Lactococcus and Acetobacter growing in a strong specific relationship. Kefir grains constitute both lactose-fermenting yeasts (Kluyveromyces marxianus) and non-lactose-fermenting yeasts (Saccharomyces unisporus, Saccharomyces cerevisiae and Saccharomyces exiguus). The pivotal indicator for sensory characteristics of Kefir is carbon dioxide (1-2g/l) which gives refreshing and slightly effervescent taste highly cherished by consumer (Beshkova et al. 2002). Irigoyen et al. 2005 stated that Kefir contains $0.08-2 \%(\mathrm{w} / \mathrm{w})$ alcohol and about $4.5 \mathrm{pH}$. About 40 aromatic compounds namely diacetyl and acetaldehyde are present in Kefir giving its characteristic flavour and aroma.

\section{Kefir manufacture}

There are mainly two methods for manufacture of Kefir: traditional (authentic) and industrial (commercial) processing (Guzel-Seydim et al. 2010).

In the traditional method, Kefir grains are added directly to the pasteurized and cooled milk followed by incubation with stirring for approximately $24 \mathrm{~h}$ at $25-30{ }^{\circ} \mathrm{C}$. Incubation temperatures above $30^{\circ} \mathrm{C}$ encourages the growth of thermophilic LAB but is a disadvantage for yeast growth and mesophilic LAB (Rattray and O'Connel, 2011). After fermentation, the grains are separated from the milk by filtering with a sterile sieve and can be dried at room temperature and kept at cold storage in milk for the next inoculation. In industrial process Lyophilized starter cultures containing LAB and yeast are used for inoculation (Guzel-Seydim et al. 2010). This is due to difficulties in post fermentation necessities of the Kefir grain separation at the end of fermentation. In this method, activated starter culture is added to homogenized and pasteurized milk containing $2-5 \%$ milk fat. Following fermentation at $25-30{ }^{\circ} \mathrm{C}$ for a period of $20-24 \mathrm{~h}$, the product can be stored at refrigerated temperature up to 20 days (Guzel-Seydim et al. 2010).

The maturation consists of maintaining kefir at $8-10{ }^{\circ} \mathrm{C}$ for up to $24 \mathrm{~h}$ (Beshkova et al. 2002; Rattray and O’Connel, 2011) to allow microorganisms primarily yeast grow contributing to the particular flavour of the product (Beshkova et al. 2002). There is rise in dimension and amount of kefir grains about 5-7\% (Leite et al. 2012) of the biomass throughout fermentation. These grains can maintain their activity for years when preserved carefully (LopitzOtsoa et al. 2006; Rattray and O'Connel, 2011). Mitra and Ghosh (2017) described the detailed production process of Kefir (Fig. $1)$.

The industrial manufacture of Kefir using grains as the starter culture is very difficult due to the complexity of their microbiological composition, which varies widely depending on the origin of the grains and conditions of storage and handling. Therefore, currently, there are commercial lyophilized starter cultures that mimic the microbial composition of the grains.

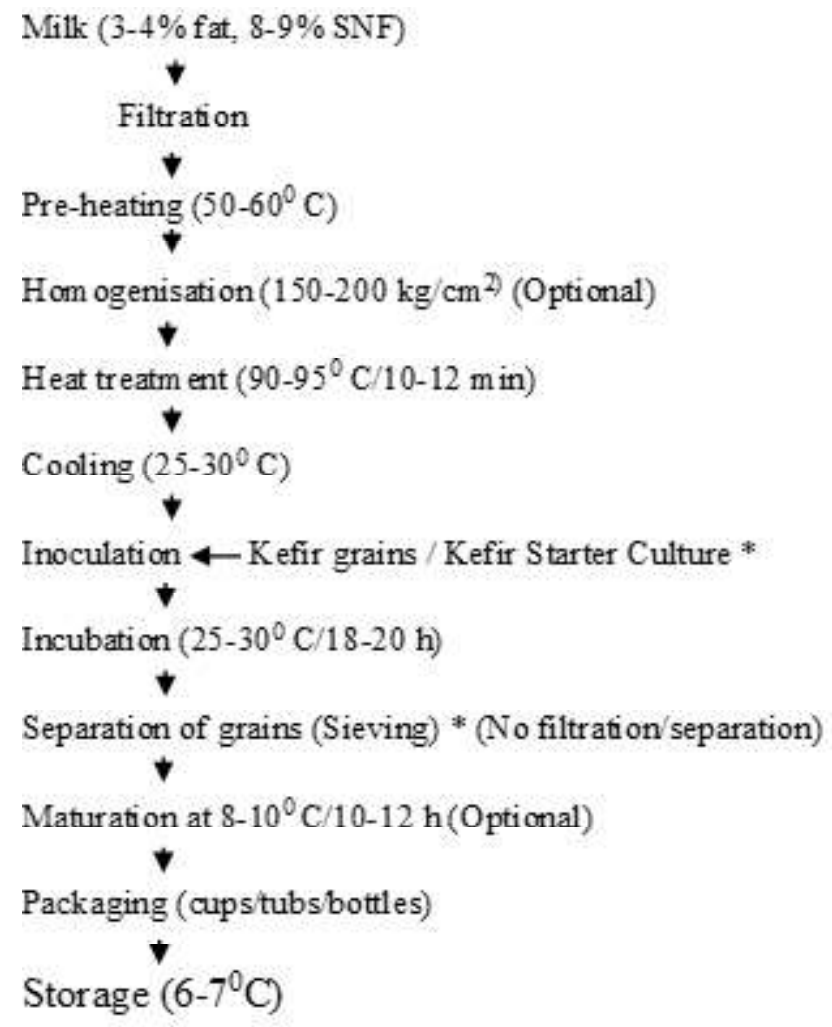

Fig. 1 Process flow for Kefir production

\section{Chemical composition of Kefir}

Investigators have perceived that composition of kefir products varies greatly and may be attributed to source and the fat content of milk, nature of the grains or cultures and the manufacturing 
process. Fermentation produces amino acids such as valine, leucine, lysine and serine while alanine and aspartic acid increases as compared to starter milk (Table 1). Substantial quantities of pyridoxine, vitamin $\mathrm{B}_{12}$, folic acid and biotin have been reported to be produced during kefir production, depending upon the origin of kefir grains whereas thiamine and riboflavin levels were reduced (Kneifel and Mayer, 1991).

The most important products formed during fermentation are lactic acid (0.8-1\%), alcohol (0.01-2\%), acetic acid (0.4\%) and $\mathrm{CO}_{2}$ (1-4 mg/L). The ash content of Kefir samples was found to range from 0.55 to $0.66 \%$. (Kök-Taş et al. 2014). More than $90 \%$ of lactic acid formed in Kefir is L (+) lactic acid. L (+) lactic acid is digested easily by the body and has physiological importance. Hydrolysis of lactose and enhanced microbial beta-galactosidase enzyme activity help lactose intolerant people who can consume Kefir easily. On the other hand, Kefir is a good source for B group vitamins, vitamin $\mathrm{K}$ and folic acid. Important aromatic compounds found in Kefir are diacetyl, acetoin and acetaldehyde. Diacetyl is harvested by Streptococcus lactis sp. diacetylactis and Leuconostoc sp. (Otles and Cagindi, 2003).

It was determined that Kefir increases secretion of some organs such as stomach and pancreas, and is helpful for nervous disorders, anorexia and insomnia. It was also found to be beneficial for high blood pressure, bronchitis and biliary disorders. Daily intake of half litre of Kefir for a day has positive effects for liver, gall and kidney functions in addition to stabilized effect on the metabolism. Kefir is effective for the functioning of kidneys, liver and nervous system because of it B vitamins content, and calcium and magnesium play role for the formation of healthy nervous system (Ahmed et al. 2013).

Sarkar (2007) indicated typical composition of Kefir as follows: $89-90 \%$ moisture, $0.2 \%$ lipid, $3.0 \%$ protein, $6.0 \%$ sugar, $0.7 \%$ ash and $1.0 \%$ each of lactic acid and alcohol while Beshkova et al. (2002) reported that Kefir contains $1.98 \mathrm{~g} / \mathrm{L}$ of $\mathrm{CO}_{2}$ and $0.48 \%$ alcohol. The amount of $\mathrm{CO}_{2}$ in Kefir varies with the concentration of Kefir grains (10-100g/L) (Garrote et al. 1998).

In another study it was observed that Kefir grains contain $86.3 \%$ moisture, $4.5 \%$ protein, $1.2 \%$ ash and $0.03 \%$ fat (Liut kevicius and Sarkinas, 2004) while Brazilian kefir was found to contain $3.91 \%$ protein, $2.34 \%$ fat and $9.62 \%$ dry matter after $24 \mathrm{~h}$ of fermentation (Magalhaes et al. 2011).

\section{Nutritional composition of Kefir}

Table 1 Compositional details of milk Kefir

\begin{tabular}{llll}
\hline Components & $100 \mathrm{~g}$ & Components & $100 \mathrm{~g}$ \\
\hline Energy & $65 \mathrm{kcal}$ & Mineral content (g) & \\
Fat (\%) & 3.5 & Calcium & 0.12 \\
Protein (\%) & 3.3 & Phosphorus & 0.10 \\
Lactose (\%) & 4.0 & Magnesium & 0.12 \\
Water (\%) & 87.5 & Potassium & 0.15 \\
Milk acid (g) & 0.8 & Sodium & 0.05 \\
Ethyl alcohol (g) & 0.9 & Chloride & 0.10 \\
Lactic acid (g) & 1 & Trace elements & \\
Cholesterol (mg) & 13 & Iron (m) & 0.05 \\
Phosphates(mg) & 40 & Copper $(\mathrm{mg})$ & 12 \\
Essential amino acids (g) & & Molybdenum $(\mu \mathrm{g})$ & 5.5 \\
Trytophan & 0.05 & Manganese $(\mu \mathrm{g})$ & 5.0 \\
Phenylalanin+tyrosine & 0.35 & Zinc(mg) & 0.36 \\
Leucine & 0.34 & Aromatic compounds & \\
Isoleucine & 0.21 & Acetaldehyde & \\
Threonine & 0.17 & Diacetyl & \\
Methionine-cystine & 0.12 & Acetoin & \\
Lysine & 0.27 & - & - \\
Valine & 0.22 & - & - \\
Vitamins (mg) & & - \\
A & 0.06 & B & 0.5 \\
Carotene & 0.02 & Niacin & 0.09 \\
$B_{1}$ & 0.04 & C & 1 \\
$B_{2}$ & 0.17 & D & 0.08 \\
$B_{6}$ & 0.05 & E & 0.11 \\
\hline A & &
\end{tabular}

Adopted from Otles and Cagindi (2003) 
Vitamins $\mathrm{B}_{5}, \mathrm{~B}_{2}$ and $\mathrm{B}_{12}$ are present in Kefir at approximate rate of $3,<5$ and $<10 \mathrm{mg} / \mathrm{kg}$, respectively (Liut kevicius and Sarkinas, 2004). It also contains vitamins A, K and carotene (Table 1). Proteins present in Kefir are complete and partly digested aiding digestion by the body (Otles and Cagindi, 2003). During fermentation of Kefir, the amino acid profile changes leading to increased levels of threonine, serine, alanine, lysine and ammonia as compared to milk. Other amino acids namely valine, isoleucine, methionine, lysine, phenylalanine and tryptophan were also reported in Kefir (Otles and Cagindi, 2003; Sarkar, 2007).

In addition to basic nutrients increased level of amino acids, proteins, phosphorus, and calcium have been reported in Kefir making it an acceptable food product particularly in regions where it is consumed as staple food (Vinderola et al. 2004). Kefir contains phosphorus in abundance aiding in utilization of carbohydrates, fats and proteins for development, reconstruction and strength of cell (Otles and Cagindi, 2003). It is also a good source of calcium and magnesium. In one study Liut kevicius and Sarkinas (2004) examined the macro- and micro-elements in Kefir and showed that Kefir grains contain following macroelements: potassium, $1.65 \%$; calcium, $0.86 \%$; phosphorus, $1.45 \%$; and magnesium, $0.30 \%$ as well as micro-elements like $(\mathrm{mg} / \mathrm{kg})$ copper, 7.32; zinc, 92.7; iron, 20.3; manganese, 13.0; cobalt, 0.16; and molybdenum, 0.33 .

Some important aspects on nutritional importance are summarized as follows.

\section{Vitamin content}

Some investigators are of the opinion that vitamins namely pyridoxine, vitamin $\mathrm{B}_{12}$, folic acid, and biotin are produced in greater amount while a decline in thiamine and riboflavin content may occur during Kefir fermentation ( Liut kevicius and Sarkinas, 2004). In addition to vitamin B-complex, substantial amount of vitamin K (Otles and Cagindi, 2003) and vitamin C (Khamnaeva et al. 2000) is also present in Kefir. Commercially accessible Kefir grains too tend to increase folic acid content of the product after fermentation (Alm, 1982).

\section{Protein content}

It has been well established that when Kefir grains were added as cultures in whey and soymilk, the protein content of the product increased as compared to whole milk. (FilChakova and Koroleva, 1997, Abraham and Antoni, 1999). Some scientists have reported proteolytic activity in Kefir (Yuksekdag et al. 2004a) which has been attributed to the presence of lactococci (Otles and Cagindi, 2003; Yuksekdag et al. 2004a).

\section{Sugar content}

Kefir contains about 6\% sugar (Ozer and Ozer, 1999) and is known as kefiran which is a heteropolysaccharide, glucogalactan in

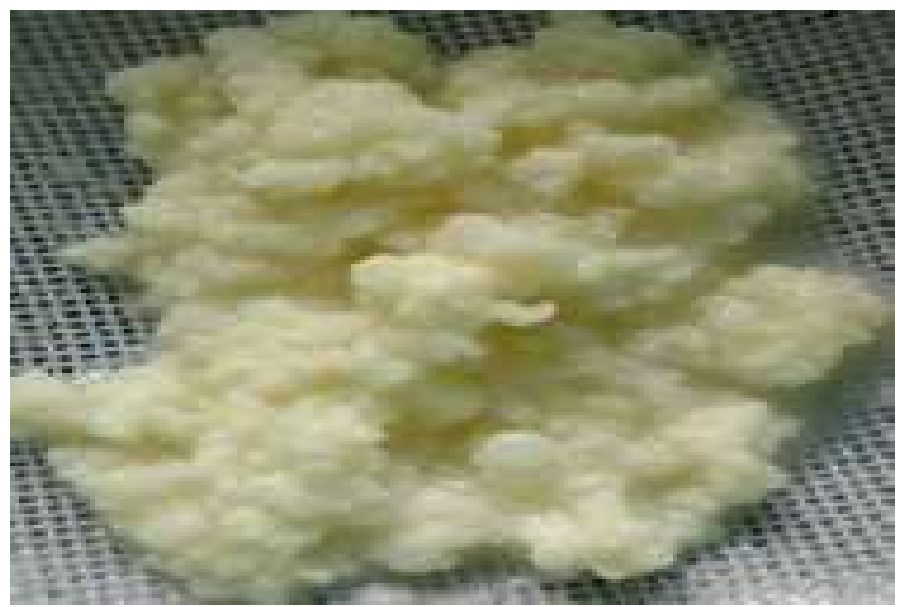

Fig. 2 Kefir grains

nature. It forms the key portion of gelatinous matrix containing microflora of Kefir. Rimada and Abraham (2006) has reported that kefiran enhances gel formation, rheology, and viscoelastic characteristics in gels produced by acidified milks and also produces gel at low temperatures. In addition to this it has also been stated that Kefir polysaccharides have numerous health improving properties namely inhibiting action on rotavirus (Song et al. 2007), immunomodulation, protection of epithelium.

\section{Mineral content}

A substantial content of major and minor minerals has been reported in Kefir namely calcium, potassium, phosphorus, magnesium and zinc, copper, manganese, iron, molybdenum, cobalt respectively. (Liut kevicius and Sarkinas, 2004).

\section{Kefir grains}

Milk is inoculated with Kefir grains for the preparation of Kefir (Fig. 2). They comprise of blend of microorganisms combined with casein and complex sugars by a matrix of polysaccharides called kefiran (Güzel-Seydim et al. 2005). Kefiran is a water-soluble branched glucogalactan (Leeet al. 2007) with hexasaccharide repeating unit composed of three glucose and three galactose residues (Maeda et al. 2004, Mukai et al. 1990). They are yellowish white elastic, slimy and irregularly shaped resembling cauliflower buds (Fig 2). Their size generally varies from 1-3 cm in length. (Farnworth, 2005, Leite et al. 2013a). A unique symbiotic relationship exists between lactic acid bacteria (LAB), yeast (lactose-fermenting and lactose non-fermenting) and sometimes acetic acid bacteria in Kefir grains (AAB) (Farnworth 2005a; Leite et al. 2013a, b). Selected microorganisms from Kefir grains constitute Kefir starter.

\section{Microbial composition of Kefir grains}

Kefir grains have variable microbial composition which is governed by their geographic origin, climatic conditions, method 
of manufacture of Kefir (time and temperature of incubation, agitation, grain to milk ratio) as well as the type of milk used for sub-culturing the grains ( Filipcev et al. 2007; Dobson et al. 2011; Leite et al. 2013b). It has following chemical composition ( $\% \mathrm{w} /$ w): water (89-90), lipids (0.2), proteins (3.0), sugar (6.0), and ash (0.7). Preservation of these grains can be done by freezing, lyophilization, and refrigeration. Kefir grains microflora produce lactic acid, acetic acid, ethanol, peptides and other biologically active components thereby increasing the storage capability of milk and hindering the growth of detrimental and pathogenic microorganisms.

Lactic acid bacteria comprise $83-90 \%$ of the Kefir grains microflora while yeasts represent $10-17 \%$ with predominant lactose-negative yeast species (66-100\%). Bergmann et al. (2010) counted the total average Lactobacillus as $8.5 \times 10^{5} \mathrm{CFU} / \mathrm{g}$ in Kefir grains. Kefiran a metabolite from Kefir, has been tested to have technological roles as a thickener, gelling agent and emulsifier (Farnworth, 2005a; Ahmed et al. 2013). Analysis of Kefir grains revealed the following bacteria: Leuconostoc ssp., Lactobacillus lactis cremoris, Chyseomonas luteola, Acetobacter and yeasts: Sacharomyces cerevisae, Candida colliculosa, Toruspola delbruechii, Candida inconspicua, Candida magnoliae, Kloekera sp., Candida famata, Kluyveromices lactis, Kluyveromices marxianus and Candida kefir are present in Kefir.

Moreover, the dispersal of microorganisms in Kefir grains is not equal. For example, while Lb. kefir strains are present on the outer surface of the grains, Lb. kefiranofacies are found in almost every region of the grains and the highest population is in the centre. Similarly, lactose-positive yeasts are detected mostly on the surface while lactose-negative yeasts at the centre. Contaminating microbes generally isolated from Kefir grains are Geotricum, Pediococcus, Micrococcus, Enterococcus and coliforms species (Seiler, 2003).

Kefiran is an exopolysaccharide component of Kefir that has significant importance in human health and nutrition and is recognized in most of the regions on this globe such as Central Asia, Southwest Asia, Japan, the Middle East, North America, Northern and Eastern parts of Europe, former USSR and North Africa (Koroleva, 1982; Otles and Cagindi, 2003; Piermaria et al. 2009). Especially in Soviet countries, Kefir has been used as prophylactic to lessen the threat of chronic diseases and has also been suggested for healing gastrointestinal diseases, IHD, allergy, and hypertension (St-Onge et al. 2000; Farnworth and Mainville, 2003). Bacterial population in Kefir ranges between $6.4 \times 10^{4}$ to $8.5 \times 10^{8} \mathrm{cfu} / \mathrm{g}$, and for yeasts, it ranges between 1.5 $\times 10^{5}$ to $3.7 \times 10^{8} \mathrm{cfu} / \mathrm{g}$ (Witthuhn et al. 2004).

The microbial population in Kefir grain was found to consist primarily of lactobacilli (65-80\%) (Wouters et al. 2002), with lactococci and yeasts comprising the remainder. Witthuhn et al.
(2004) reported that $\mathrm{LAB}$ and yeast level present in kefir grains vary widely, ranging from $6.4 \times 10^{4}$ to $8.5 \times 10^{8}$ and $1.5 \times 10^{5}$ to 3.7 $\times 10^{8} \mathrm{cfu} / \mathrm{mL}$, respectively. Irigoyen et al. (2005) reported that in addition to a viable population of $10^{8} \mathrm{cfu} / \mathrm{mL}$ of lactobacilli and lactococci and $10^{5} \mathrm{cfu} / \mathrm{mL}$ of yeasts, Kefir also contained $10^{6}$ $\mathrm{cfu} / \mathrm{mL}$ acetic acid bacteria after $24 \mathrm{~h}$ of fermentation. The amounts of yeast in Kefir vary from $10^{3}$ to $10^{6}$ (Grønnevik et al. 2011; GuzelSeydim et al. 2005; Irigoyen et al. 2005; Simova et al. 2002). Grønnevik et al. (2011) found that the LAB count in kefir samples decreased during the first 4 weeks of storage, whereas yeast levels increased throughout the storage period.

\section{Preparation of Kefir grains}

The process for the preparation of Kefir has been described by Otles and Çagýndý (2003). A sterile water washed goat-hide bag filled with pasteurized milk and intestinal flora of a sheep was used. The temperature was maintained at $25^{\circ} \mathrm{C}$ for 2 days with every hour shaking. For a period of 12 weeks, three quarters of it was replaced with fresh milk immediately after coagulation. As a polysaccharide layer developed on the surface of the hide, it was removed and promulgated in pasteurized cow milk. This way kefir grains were developed and grown in fresh milk daily.

\section{Activation of Kefir grains}

Activation of lyophilized kefir grains can be done by inoculating sterilized skim milk ( $0.1 \%$ milk fat, $1 \mathrm{~L}$ flask, $\left.115^{\circ} \mathrm{C} / 15 \mathrm{~min}\right)$ at 18 $20^{\circ} \mathrm{C}$ in $1: 10$ ratio followed by incubation for $24 \mathrm{~h}$ with $3-5$ mixings. After fermentation the grains were recovered by filtering the product and were used for next culturing after being washed with sterile water. (Simova et al. 2002). Cultivation of kefir grains in broth (distilled water with 5\% brown sugar) was done through incubation at $25^{\circ} \mathrm{C}$ for $24 \mathrm{hr}$ (Bergmann et al. 2010). Reactivation was followed by washing with distilled water and sub-cultivation in the same broth every 24 hours for a period of 15 days.

\section{Preservation of Kefir grains}

Freezing was considered as the best method for the preservation of Kefir grains (Garrote et al. 1997) besides lyophilisation can be done (dry/wet). Activity of dried grains last for about 12-18 months while for wet grains it is 8-10 days (Garrote et al. 2010). The disadvantage of this method is reduced lactose metabolism due to modification in bacteriological profile as compared to the original grains.

\section{Kefir Culture versus Kefir grains}

Several percentages of starter cultures isolated from the grains (LAB-Lactic Acid Bacteria, yeast, AAB-Acetic Acid Bacteria) were verified and it was found that traditional Kefir produced with Kefir grains was better acknowledged than kefir from starter culture (Assadi et al. 2000) while Carneiro (2010) developed a 
starter culture from microorganisms isolated from Kefir grains and the product was more accepted than the traditional kefir.

Standardization of commercial production of kefir can be done using commercial cultures thereby allowing production of "kefir type" beverage with suitable flavour and good preservation properties (Beshkova et al. 2002; Carneiro, 2010). Commercial beverages may have commercial life up to 28 days while kefir prepared with grains must be consumed between 3-12 days (Leite et al. 2013b)

\section{Therapeutic properties}

The Kefir microbial metabolites and bioactive compounds are the outcome of yeast and bacterial action. The benefits associated with the consumption of Kefir reflected in the intestinal microbiota due to the inhibition of pathogens by acids and bacteriocin production in the intestinal mucosa.

\section{Anticarcinogenic effect}

In an experiment, an oral dose of 100 or $500 \mathrm{mg} / \mathrm{kg}$ of Kefir reported major reduction of tumour size in mice artificially transplanted with solid tumours of E-ascites carcinoma through stimulation of immunosuppressive action in spleen (Kubo et al. 1992). Strains of Lactobacillus, Streptococcus, Leuconostoc and Streptococcus lactis subsp. cremoris (Miyamoto et al. 1991) isolated from Kefir are capable of binding mutagens. However,
Kefir from soymilk has been proved to be the best among all these (Liu et al. 2002).

Kefiran isolated from Kefir grains or harvested by $L$. kefiranofaciens has been reported to possess antitumor activity. It has been observed that sulphur containing amino acids play a key role in anticarcinogenic activity of Kefir and similar products (Guzel-Seydim et al. 2003). Liu et al. (2002) examined tumour inhibitory effect of Kefir prepared from soy milk and cows' milk with Kefir grains in mice. Both soy milk Kefir (70.9\%) and cows' milk Kefir (64.8\%) significantly inhibited tumour growth, compared with mice in the positive control group.

\section{Antibacterial spectrum}

The antibacterial properties of Kefir may be attributed to the integral formation of organic acids, hydrogen peroxide, acetaldehyde, carbon dioxide, and bacteriocins. It has been shown by Yuksekdag et al. (2004a) that 21 isolates of lactic acid bacteria from Turkish Kefir produced hydrogen peroxide in the range $0.04-0.19 \mu \mathrm{g} / \mathrm{ml}$. Lacticin 3147, a bacteriocin produced by Lactococcus lactis strain DPC3147 from Kefir grains showed activity against Escherichia Coli, Listeria monocytogenes, Salmonella typhimurium, S. enteritidis, S. flexneri, and Yersinia enterocolitica (Santos et al. 2003). Medrano et al. (2008) stated that $300-1000 \mathrm{mg} / \mathrm{L}$ of kefiran from Kefir grains gave protection against damage to Caco-2 cells by Bacillus cereus B 10502

Table 2 Differences between Kefir and Yoghurt

\begin{tabular}{lcc}
\hline Characteristics & Kefir & Yoghurt \\
\hline Culture & Mesophilic & Thermophilic \\
Temperature & Moderate $\left(25-30^{\circ} \mathrm{C}\right)$ & Warm $\left(42-46^{\circ} \mathrm{C}\right)$ \\
Milk & Works well with raw milk & Works well with pasteurized milk \\
Main metabolites & Lactic acid, $\mathrm{CO}_{2}$, alcohol, Kefiran & Lactic acid \\
Colonization & Recolonization in gut with probiotics & No colonization in gut \\
\end{tabular}

Table 3 Differences between Kefir and Dahi

\begin{tabular}{lll}
\hline Characteristics & Kefir & Dahi \\
\hline Culture & Kefir is prepared by fermenting & Dahi is prepared by \\
& milk with Kefir grains & fermenting milk with Dahi culture \\
Texture & Uniform due to sieving & Grainy and sometimes pasty \\
Shelf-life & More & Less \\
Flavour & Yeasty with prickly sensation & Diacetyl flavour \\
Base medium & Milk/ Whey/Water & Milk \\
Maturation & Done to obtain typical flavour of kefir & Not done \\
Nature & Probiotic in nature & May or may not be probiotic \\
& & unless probiotic organisms are added \\
Consistency & Mostly pourable & Pourable or set type \\
Immunomodulation & Kefiran is major immune & No specific immune \\
& modulating component produced by kefir grains & modulating component is present
\end{tabular}


Kefir contains innate components from milk that hinder pathogens by primary and secondary metabolites namely small peptides, diacetyls, and organic acids harvested by microflora in Kefir (Golowczyc et al. 2008). Czamanski et al. 2004) reported that Kefir generally shows bacteriostatic effect on Gram-negative organisms however it has improved bactericidal effect against Gram-positive organisms. Kefir has shown antagonistic effect against Listeria monocytogenes, Yersinia enterocolitica, Escherichia coli (Gulmez and Guven, 2003), Listeria innocua (Morgan et al. 2000) and Salmonella enteritidis (Czamanski et al. 2004; Golowczyc et al. 2007). Undissociated acetic and lactic acid harvested by acetic acid bacteria and yeasts contribute to their bactericidal effect (Garrote et al. 1998). Besides LAB produces $\mathrm{H}_{2} \mathrm{O}_{2}$ which also lead to such diminishing effect (Yuksekdag et al. 2004a; Yuksekdag et al. 2004b)

\section{Effect on immune system}

Many researchers are of the view that Kefir may have immunomodulatory and prodigestive effect (Zhou et al. 2009). Vinderola et al. (2005) described that on consumption of Kefir both pulmonary and peritoneal macrophages lessen the pathogenic action there by affecting the mucosal response at various regions in the body in a murine (mice/ rodent) model. In another study an increased anti-cholera toxin (CT) IgA response was seen compared to controls in Kefir-fed young and old rats (6-26 months) through improved mucosal immune reaction.

\section{Anti-inflammatory}

Many studies have shown Kefir and its kefiran extract to possess anti-inflammatory activity. They exhibit this activity by preventing the formation of granuloma tissue (Rodrigues et al. 2005). They exhibit variable levels of anti-inflammatory activity such as in case of suspensions with molasses, fermented milk and kefiran extract an inhibition of 41,44 , and $34 \%$, respectively have been reported.

\section{Hypocholesterolemic effect}

LAB present in Kefir can act on cholesterol through their metabolic products ensuring up to $30 \%$ binding of cholesterol. Vujicic et al. (1992) reported that 28-65\% assimilation of cholesterol occurs when milk is inoculated with Kefir culture followed by incubation at $24.8^{\circ} \mathrm{C}$ for $24 \mathrm{~h}$. In another study Wang et al. (2009) have established cholesterol lowering activity of Lactobacillus plantarum MA2 isolated from Chinese Tibet Kefir. Liu et al.(2006a) stated that total cholesterol lowering properties of soymilk Kefir was found to be equally effective as milk Kefir and it also lowered serum triacylglycerol, and LDL cholesterol. All these studies reveal that Kefir and its components are prospective hypocholesterolaemic substance (Maeda et al. 2004; Liu et al. 2006a).

\section{B-Galactosidase activity}

$\beta$-galactosidase enzyme is naturally present in Kefir grains. It hydrolyses lactose making it suitable for lactose intolerant people (De Vrese et al. 1992). Hertzler and Clancy (2003) stated that a starter culture comprising of six bacteria (but not L. acidophilus) and one yeast produced Kefir which was equally effective in decreasing breath hydrogen in adult lactose maldigestions as compared to yoghurt. It has also been established that Kefir has some amount of $\beta$ - galactosidase activity, converting lactose into easily digestible glucose and galactose thereby improving lactose tolerance.

\section{Gastrointestinal proliferation}

There is a wide believe that Kefir exerts prodigestive effect in gastrointestinal tract. Fil Chakova and Koroleva (1997) have stated that daily consumption of Kefir not only benefits gastrointestinal disorders but also helps in rapid healing in postoperative cases. Kefiran, exopolysaccharide of Kefir can alleviate the detrimental effect of $B$. cereus. In addition to this, it can control the virulence of microorganisms regarding intestinal infections (Medrano et al. 2008; Medrano et al. 2009).

\section{Bacterial colonization}

LAB from Kefir inhabitat in the intestine for brief period but produce favourable factors (probiotic). They are exceptionally tolerant to consecutive gastrointestinal tract situations. Santos et al. (2003) stated that 85\% Lactobacillus species isolated from Kefir can stick to enterocyte like cells. Kefiran acts as a shield for LAB in hostile environments. Mitra and Ghosh (2019) incorporated probiotic organism of Lactobacillus rhamnosus GG along with kefir grains to manufacture and evaluated its quality characteristics for improved bacterial colonization .

\section{Antiallergic properties}

Daily intake of milk Kefir and soy-based Kefir products confine the IgE and IgG responses. Thus, gut microflora modification can be achieved with Kefir to inhibit food allergy and improve mucosal resistance in case of gastrointestinal pathogen infections (Liu et al. 2006b). In another study Lee et al. (2007) discovered that prevention of ovalbumin-induced eosinophilia in lung tissue and mucus hypersecretion can be achieved with Kefir thereby establishing itself as a potential therapeutic agent in management of allergic bronchial asthma.

\section{Protection against apoptosis}

Kefiran of Kefir have scavenging effect on superoxide radicals thereby giving protection against UV damage of human melanoma HMV-1 cells (Nagira et al. 1999). Matsuu et al. (2003) stated that milk Kefir reduced X-ray-induced apoptosis in rat's colon. In another study it was demonstrated that Kefir exhibited protection against apoptosis for colonic epithelial stem cells through termination of caspase- 3 stimulation. Consumption of 
Kefir may reduce the adverse side effects of irradiation in malignant patients undergoing irradiation therapy (Nagira et al. 1999; Matsuu et al. 2003).

\section{Wound healing properties}

It has been reported that the anti-inflammatory properties of polysaccharide present in Kefir extract may lead to the process of wound healing (Chena et al. 2008). Huseini et al. (2012) observed that lactic acid, acetic acid, polysaccharides and other chemicals present in Kefir were influential in wound healing. They also demonstrated that Kefir had improved wound-healing properties than conventional silver sulfadiazine treatment with respect to thermal injuries. Sugar prebiotics and peptide for example lactacin, bacteriocins, and kefiran are also present in Kefir (Schneedorf and Anfiteatro, 2004).

\section{Antioxidant properties}

Kefir samples were examined for antioxidant properties such as inhibition of ascorbate autoxidation, reducing activity, superoxide anion radicals and hydrogen peroxide scavenging activity. The maximum degree of inhibition was observed in whole soymilk Kefir. No hydrogen peroxide scavenging activity was displayed by the Kefir samples. The differences between Kefir \& Yoghurt (Table 2) and Kefir \& Dahi (Table 3) have been lighted.

\section{Conclusions}

In general, an increasing trend to consume nutritive foods possessing certain health benefits has been observed across the globe. This trend paved the way for regular consumption of cultured products like Kefir. Kefir has acquired increased preferences owing to neutraceutical and therapeutic potential. Several constituents like protein, vitamins, antioxidants, minerals, and certain metabolites contribute towards beneficial properties of Kefir. Numerous health benefits namely anticarcinogenic effect, gastrointestinal proliferation, antidiabetic properties, $\beta$ galactosidase activity etc. have been associated with Kefir. It has been reported (Koroleva, 1998) that kefir have been regularly used for managing numerous metabolic disorders, allergic disease, chronic enteritis etc. at hospitals of former Soviet Union. Consumption of Kefir has been advised for infants, children, women and individuals with lactose intolerance (Otles and Cagindi, 2003). Researches are in progress to identify organisms in complex microbiology of Kefir. Numerous bacteria from Kefir grains exhibited proteinase activity and certain bioactive peptides have also been identified in Kefir. Efforts have been made to industrially manufacture Kefir using starter culture isolated from Kefir grains. However, more research is required in this regard for obtaining traditional flavour along with other characteristics of Kefir.

\section{References}

Abraham AG, de Antoni GL (1999) Characterization of kefir grains grown in cows' milk and in soya milk. J Dairy Res 66: 327-333

Ahmed Z, Wang Y, Ahmad A, Khan ST, Nisa M, Ahmad H, Afreen A (2013) Kefir and health: a contemporary perspective. Critical Rev Food Sci Nutr 53: 422-434

Alm L (1982) Effect of fermentation on milk fat of Swedish fermented milk products. J Dairy Sci 65: 521-530

Assadi MM, Pourahmad R, Moazami N (2000) Use of isolated kefir starter cultures in kefir production. World J Microbiol Biotechnol 16: 541543

Bergmann RSDO, Pereira MA, Veiga SMOM, Schneedorf JM, Oliveira NDMS, Fiorini JE (2010) Microbial profile of a kefir sample preparations: grains in natura and lyophilized and fermented suspension. Food Sci Technol (Campinas) 30: 1022-1026

Bergmann RSDO, Pereira MA, Veiga SMOM, Schneedorf JM, Oliveira NDMS, Fiorini JE (2010) Microbial profile of a kefir sample preparations: grains in natura and lyophilized and fermented suspension. Food Sci Technol 30: 1022-1026

Beshkova DM, Simova ED, Simov ZI, Frengova GI, Spasov ZN (2002) Pure cultures for making kefir. Food Microbiol 19: 537-544

Carneiro RP (2010) M.Sc. Dissertation. Belo Horizonte, Brasil: Faculdade de Farmácia. UFMG. Desenvolvimento de uma cultura iniciadora para produção de kefir pp 142. [Google Scholar]

Chen HC, Wang SY, Chen MJ (2008) Microbiological study of lactic acid bacteria in kefir grains by culture-dependent and culture-independent methods. Food Microbiol 25: 492-501

Czamanski RT, Greco DP, Wiest JM (2004) Evaluation of antibiotic activity in filtrates of traditional kefir. Higiene Alimentar 18: 7577

De Vrese M, Keller B, Barth CA (1992) Enhancement of intestinal hydrolysis of lactose by microbial $\beta$-galactosidase (EC 3.2. 1.23) of kefir. British J Nutr 67: 67-75

Dobson A, O'Sullivan O, Cotter PD, Ross P, Hill C (2011) High-throughput sequence-based analysis of the bacterial composition of kefir and an associated kefir grain. FEMS Microbiol Letters 320: 56-62

Dufresne C, Farnworth E (2000) Tea, Kombucha, and health: a review. Food Res Int 33: 409-421

Farnworth ER, Mainville I (2003) Kefir: a fermented milk product. Handbook of Fermented Functional Foods 2: 89-127

Farnworth ER (2005) Keûr-a complex probiotic. Food Sci Technol Bull: Fu 2: $1-17$

Farnworth ER (2005a) The Beneficial health effects of fermented foodspotential probiotics around the world. J. Nutraceuticals, Functional Med Foods 4: 93-117

FilChakova SA, Koroleva NS (1997) The influence of culturing conditions on the composition and microflora of kefir grains. Mol Prom 5: 37

Filipcev B, Šimurina O, Bodroža-Solarov M (2007) Effect of native and lyophilized kefir grains on sensory and physical attributes of wheat bread. J Food Processing Preservation 31: 367-377

Garrote GL, Abraham AG, De Antoni GL (1998) Characteristics of kefir prepared with different grain [ratio] milk ratios. J Dairy Res 65: 149-154

Garrote GL, Abraham AG, De Antoni GL (1997) Preservation of kefir grains, a comparative study. LWT-Food Sci Technol 30: 77-84

Garrote G L, Abraham AG, De Antoni GL (2010) Microbial Interactions in Kefir: A Natural Probiotic Drink. In: Mozzi, F., Raya, R.R. and Vignolo, G.M., Eds., Biotechnology of Lactic Acid Bacteria, Wiley- 
Blackwell, Ames, IO, 327-340. http://dx.doi.org/10.1002/ 9780813820866.ch18

Golowczyc MA, Gugliada MJ, Hollmann A, Delfederico L, Garrote G L, Abraham AG, De Antoni G(2008) Characterization of homofermentative lactobacilli isolated from kefir grains: potential use as probiotic. J Dairy Res 75: 211-217

Golowczyc MA, Mobili P, Garrote GL, Abraham AG, De Antoni GL (2007) Protective action of Lactobacillus kefir carrying S-layer protein against Salmonella enterica serovar Enteritidis. Int J Food Microbiol 118: $264-273$

Grønnevik H, Falstad M, Narvhus JA (2011) Microbiological and chemical properties of Norwegian kefir during storage. Int Dairy J 21: 601606

Gulmez M, Guven A (2003) Survival of Escherichia coli O157: H7, Listeria monocytogenes $4 \mathrm{~b}$ and Yersinia enterocolitica $\mathrm{O} 3$ in different yogurt and kefir combinations as prefermentation contaminant. J Appl Microbiol 95: 631-636

Guzel-Seydim ZB, Seydim Z, Greene AK (2003) Comparison of amino acid profiles of milk, yogurt and Turkish Kefir. Milchwissenschaft 58:158-160

Guzel-Seydim Z, Wyffels J, Seydim A, Greene AK (2005) Turkish kefir and kefir grains: microbial enumeration and electron microscopic observation. Int J Dairy Technol 58: 25-29

Guzel-Seydim Z, Kök-Taş T, Greene AK (2010) Kefir and koumiss: Microbiology and technology. In Development and Manufacture of Yogurt and Other Functional Dairy Products, CRC Press Boca Raton, FL., pp. 143-163

Hertzler SR, Clancy SM (2003) Kefir improves lactose digestion and tolerance in adults with lactose maldigestion. J American Dietetic Association 103: 582-587

Huseini FH, Golnar R, Mohammad RF, Mitra M, Mitra S(2012) Evaluation of wound healing activities of kefir products. Burns 38: 719-723

Irigoyen A, Arana I, Castiella M, Torre P, Ibanez FC (2005) Microbiological, physicochemical, and sensory characteristics of kefir during storage. Food Chem 90: 613-620

Khamnaeva NI, Tsyrenov VZ, Gongorova VS, Shalygina AM (2000) Biosynthesis of biologically active substances in kefir grains. Molochnaya Promyshlennost' 4:49

Kneifel W, Mayer HK (1991) Vitamin profiles of kefirs made from milks of different species. Int J Food Sci Technol 26: 423-428

Koroleva NS (1998) Technology of kefir and kumys, Bull. G.L., Characteristics of kefir prepared with different grain:milk ratios. J Dairy Res 65: 149-154

Koroleva NS (1988) Starters for fermented milks. Kefir and Kumys Starters. Federation Internationale de Laiterie 227

Koroleva NS (1982) Fermented milk: Science and technology. Bull Int Dairy Federation 227: 35-40

Kubo M, Odani T, Nakamura S, Tokumaru S, Matsuda H (1992) Pharmacological study on kefir-a fermented milk product in Caucasus. I. On antitumor activity. Yakugaku Zasshi 112:489-495

Lee MY, Ahn KS, Kwon OK, Kim MJ, Kim MK, Lee IY, Lee HK (2007) Anti-inflammatory and anti-allergic effects of kefir in a mouse asthma model. Immunobiology 212(8): 647-654

Leite AMDO, Miguel MAL, Peixoto RS, Rosado AS, Silva JT, Paschoalin VMF (2013a) Microbiological, technological and therapeutic properties of kefir: a natural probiotic beverage. Brazilian J Microbiol 44: 341-349

Leite AMO, Leite DCA, Del Aguila EM, Alvares TS, Peixoto RS, Miguel M AL, Paschoalin VMF (2013b) Microbiological and chemical characteristics of Brazilian kefir during fermentation and storage processes. J Dairy Sci 96: 4149-4159

Leite AMO, Mayo B, Rachid CTCC, Peixoto RS, Silva, JT, Paschoalin VMF, Delgado S (2012) Assessment of the microbial diversity of
Brazilian kefir grains by PCR-DGGE and pyrosequencing analysis. Food Microbiol 31: 215-221

Liu JR, Wang SY, Chen MJ, Chen H., Yueh PY, Lin CW (2006a) Hypocholesterolaemic effects of milk-kefir and soyamilk-kefir in cholesterol-fed hamsters. British J Nutr 95: 939-946

Liu JR, Wang SY, Chen MJ, Yueh PY, Lin CW (2006b) The anti allergenic properties of milk kefir and soymilk kefir and their beneficial effects on the intestinal microflora. J Sci Food Agric 86: 2527-2533

Liu JR, Wang SY, Lin, YY, Lin CW (2002) Antitumor activity of milk kefir and soy milk kefir in tumor-bearing mice. Nutr Cancer 44: 183-187

Liutkevičius A, Sarkinas A (2004) Studies on the growth conditions and composition of kefir grains-as a food and forage biomass. Vet Zootec 25: $64-70$

Lopitz-Otsoa F, Rementeria A, Elguezabal N, Garaizar J (2006) Kefir: a symbiotic yeasts-bacteria community with alleged healthy capabilities. Rev Iberoam Micol 23: 67-74

Maeda H, Zhu X, Omura K, Suzuki S, Kitamura S (2004) Effects of an exopolysaccharide (kefiran) on lipids, blood pressure, blood glucose, and constipation. Biofactors 22: 197-200

Magalhaes KT, Pereira GVDM, Campos CR, Dragone G, Schwan RF (2011) Brazilian kefir: structure, microbial communities and chemical composition. Brazilian J Microbiol 42: 693-702

Matsuu M, Shichijo K, Okaichi K, Wen CY, Fukuda E, Nakashima M, Sekine I (2003) The protective effect of fermented milk kefir on radiation-induced apoptosis in colonic crypt cells of rats. J Radiation Res 44: 111-115

Medrano M, Hamet MF, Abraham AG, Pérez PF (2009) Kefiran protects Caco-2 cells from cytopathic effects induced by Bacillus cereus infection. Antonie Van Leeuwenhoek 96: 505

Medrano M, Pérez PF, Abraham AG (2008) Kefiran antagonizes cytopathic effects of Bacillus cereus extracellular factors. Int J Food Microbiol 122: $1-7$

Mitra S, Ghosh BC (2017) Kefir - an alternative fermented milk. Indian Dairyman 69: 78-81

Mitra S, Ghosh BC (2019) Quality characteristics of kefir as a carrier for probiotic Lactobacillus rhamnosus GG. Int J Dairy Technol 70: 18

Miyamoto T, Morita H, Nishioka K, Kataoka K, Izumimoto M, Kuyama $\mathrm{T}$ (1991) Constituent species of lactic acid bacteria from kefir and their desmutagenic properties. Japanese J Dairy Food Sci 40: A111A120

Morgan SM, Hickey R, Ross RP, Hill C (2000) Efficient method for the detection of microbially produced antibacterial substances from food systems. J Appl Microbiol 89: 56-62

Mukai T, Toba T, Itoh T, Adachi S (1990) Structural investigation of the capsular polysaccharide from Lactobacillus kefiranofaciens K1. Carbohydrate Res 204: 227-232

Nagira T, Narisawa J, Teruya K, Kusumoto K, Katakura Y, Barnes DW, Shirahata, S (1999) Suppression of Apoptosis in UV-Damaged Human Melanomacells by a Fermented Milk, Kefir. In Animal Cell Technology: Products from Cells, Cells as Products, Springer, Dordrecht pp 437-439

Otles S, Cagindi O (2003) Kefir: a probiotic dairy-composition, nutritional and therapeutic aspects. Pakistan J Nutr 2: 54-59

Ozer D, Ozer BH (1999) Product of Eastern Europe and Asia. In: Encyclopedia of Food Microbiology. Academic Press London, pp 798-805

Piermaria JA, Pinotti A, Garcia MA, Abraham AG (2009) Films based on kefiran, an exopolysaccharide obtained from kefir grain: development and characterization. Food Hydrocolloids 23: 684690 
Rattray FP, Connell MJ (2011) Fermented Milks Kefir. In: Fukay JW, editor. Encyclopedia of Dairy Sciences. 2nd Ed. Academic Press, San Diego, U.S.A., pp 518-524

Rimada PS, Abraham AG (2006) Kefiran improves rheological properties of glucono-ä-lactone induced skim milk gels. Int Dairy J 16: 33-39

Rodrigues KL, Carvalho JCT, Schneedorf JM (2005) Anti-inflammatory properties of kefir and its polysaccharide extract. Inflammopharmacology 13: 485-492

Santos A, San Mauro M, Sanchez A, Torres JM, Marquina D (2003) The antimicrobial properties of different strains of Lactobacillus spp. isolated from kefir. Systematic Appl Microbiol 26: 434-437

Sarkar S (2007) Potential of kefir as a dietetic beverage-a review. British Food J 109: 280-290

Schneedorf JM, Anfiteatro D (2004) Kefir, A probiotic produced by encapsulated microorganism and inflammation. Anti-inflammatory Phytotherapics (Portuguese), JCT. Carvalho, editor. Tecmed, Brazil, 443-467

Seiler H (2003) A review: yeasts in kefir and kumiss. Milchwissenschaft 58: $392-396$

Simova E, Beshkova D, Angelov A, Hristozova T, Frengova G, Spasov Z (2002) Lactic acid bacteria and yeasts in kefir grains and kefir made from them. J Industrial Microbiol Biotechnol 28: 1-6

Song JO, Kim TJ, Kim YH (2007) Inhibitory effect on rotavirus by exopolysaccharides extracted from kefir. Korean J Food Sci Anim Res 27: 538-542

St-Onge MP, Farnworth ER, Jones PJ (2000) Consumption of fermented and unfermented dairy products: effects on cholesterol concentrations and metabolism. The American J Clinical Nutr 71:674-681

Vedamuthu ER (1977) Exotic fermented dairy foods. J Food Prot 40: 801802

Vinderola CG, Medici M, Perdigon G (2004) Relationship between interaction sites in the gut, hydrophobicity, mucosal immunomodulating capacities and cell wall protein profiles in indigenous and exogenous bacteria. J Appl Microbiol 96: 230-243

Vinderola G, Matar C, Perdigon G (2005) Role of intestinal epithelial cells in immune effects mediated by gram-positive probiotic bacteria: involvement of toll-like receptors. Clin Diagn Lab Immunol 12: 1075-1084

Vujièiæ IF, Vuliæ M, Könyves T (1992) Assimilation of cholesterol in milk by kefir cultures. Biotechnol Letters 14: 847-850

Wang Y, Xu N, Xi A, Ahme Z, Zhang B, Bai X (2009) Effects of Lactobacillus plantarum MA2 isolated from Tibet kefir on lipid metabolism and intestinal microflora of rats fed on high-cholesterol diet. Appl Microbiol Biotechnol 84: 341-347

Witthuhn RC, Schoeman T, Britz TJ (2004) Isolation and characterization of the microbial population of different South African kefir grains. Int J Dairy Technol 57: 33-37

Wouters JT, Ayad EH, Hugenholtz J, Smit G (2002) Microbes from raw milk for fermented dairy products. Int Dairy J 12: 91-109

Yang Y, Shevchenko A, Knaust A, Abuduresule I, Li W, Hu X, Shevchenko A (2014) Proteomics evidence for kefir dairy in Early Bronze Age China. J Archaeol Sci 45: 178-186

Yüksekdað ZN, Aslim B, Beyatli Y, Mercan N (2004b) Effect of carbon and nitrogen sources and incubation times on poly-betahydroxybutyrate (PHB) synthesis by Bacillus subtilis 25 and Bacillus megaterium 12. African J Biotechnol 3: 63-66

Yüksekdað ZN, Beyatli Y, Aslim B (2004a) Determination of some characteristics coccoid forms of lactic acid bacteria isolated from Turkish kefirs with natural probiotic. LWT-Food Sci Technol 37: 663-667

Zhou J, Liu X, Jiang H, Dong M (2009) Analysis of the microflora in Tibetan kefir grains using denaturing gradient gel electrophoresis. Food Microbiol 26: 770-775 